\title{
Memories of War and the COVID-19 Crisis in Spain
}

\section{Ana Belén Martínez García ${ }^{1}$ (iD}

Received: 1 July 2020 / Revised: 22 August 2020 / Accepted: 1 October 2020 /

Published online: 15 November 2020

(c) Springer Nature Switzerland AG 2020

\begin{abstract}
Spaniards born in a democracy have no recollection of living through war and what it entails. We can only access those memories via mediation, by listening to our relatives who were there, whose stories we become witnesses to, and which ultimately become our own collective witnessing. The remembrance of the Spanish Civil War passed on to us in this manner is a contested legacy, a complex combination of affects and mediated memories, coming from offline - as in conversations with our elders - and online - such as archival footage-resources. Experiencing war firsthand left indelible marks in our forebearers' minds. Now the elderly must face this violent "war" and "postwar" rhetoric with the potential retraumatization it may cause. Not capable to understand why media and government officials alike call for heroes to resist and fight the crisis, a discourse heavily imbued with emotions and battlefront references does little to assuage citizens' fears. Perpetual news reels on the number of dead per day worsen the psychological strain of a person in lockdown, akin to that of prison inmates, more so if that person endured an actual war and its aftermath. What might be done to lessen such harmful impacts? How can we change the narrative and make it more humane?
\end{abstract}

Keywords Collective witnessing $\cdot$ Spanish civil war $\cdot$ Traumatic memories $\cdot$ Discursive frames $\cdot$ Crisis narrative $\cdot$ Emotions

\section{Introduction}

This article draws on Paul John Eakin's definition of narrative identity and how we are "Storied Selves" (Eakin, 1999, p. 99) whose identity is constructed through "Self-narration": "narrative is not something we tell, listen to, read, or invent; it is an essential part of who we are" (2008, p. ix). Furthermore, our lives are "relational" (1999, p. 43), meaning our identity is never only a matter of the individual but it is also collaboratively produced. Research in autobiography or life writing/life narrative, as broader umbrella terms, demonstrates those core tenets, inextricably linked to theories of emotions, sociology, psychology, and narrative.

Ana Belén Martínez García

abmartinezg@unav.es

1 Department of Communication At ISSA, School of Management Assistants, University of Navarra, Pamplona, Spain 
How traumatic experiences and violence of various kinds are negotiated via testimonial life narrative is the subject of notable scholarly works. Among those, one may count, for instance, Kay Schaffer and Sidonie Smith's (2004) Human Rights and Narrated Lives: the Ethics of Recognition. In this seminal work, Schaffer and Smith discuss manifold case studies from across the globe where violence and life narrative intersect, the frames and templates that testimonial texts draw from, and the potential and pitfalls of rights discourse. Importantly, they address the relationship between memory and witnessing:

These acts of remembering test the values that nations profess to live by against the actual experiences and perceptions of the storyteller as witness. They issue an ethical call to listeners both within and beyond national borders ... They issue a call within and beyond UN protocols and mechanisms for institutions, communities, and individuals to respond to the story; to recognize the humanity of the teller and the justice of the claim; to take responsibility for that recognition; and to find means of redress. In the specific locales of rights violations and in the larger court of public opinion, life narrative becomes essential to affect recourse, mobilize action, forge communities of interest, and enable social change. (Schaffer and Smith, 2004, p. 3).

Within the context of testimony, Gillian Whitlock (2015) attends to what she calls "testimonial transactions" (p. 1), which allow her to "track transnational and transcultural passages of life narrative, its volatile currency, and its changing technologies of the self" (p. 1). She further points out the evasive nature of trauma narratives as well as their marketability in recent times. Finally, Leigh Gilmore (2017) addresses the "co-construction" (p. 307) inherent to testimonial texts as "histories of harm and first-person witness intertwine" (p. 307). As shall be seen below, the individual and the collective ramifications of suffering cannot easily be disentangled. Rather they are to be read as part of a whole.

In the book, New Forms of Self-Narration: Young Women, Life Writing and Human Rights, Ana Belén Martínez García (2020b) looks at contemporary cases of women activists seeking to bring to light abuse they have witnessed and/or endured to call for an end to injustice, usually starting as something personal and local, but soon becoming global phenomena.

As this project was being finalized, Spain was overcome by COVID-19.

\section{The COVID-19 Crisis}

On January 12, 2020, the World Health Organization confirmed a novel coronavirus with symptoms akin to severe pneumonia had appeared in Wuhan, China. On January 30, as more cases were reported ( 98 cases in 18 countries outside China), contagion rates rapidly rising, WHO (2020a) declared a "public health emergency of international concern." With numbers of infected and dead people mounting daily, intensive media coverage around the world focused on the epidemic, though the word "pandemic" was carefully avoided for over two months, at which point 118,000 cases had been reported in 114 countries, and 4291 people had lost their lives (World Health Organization, 2020c). The actual name for the disease and the virus that causes it took also some time, with the International Committee on Taxonomy of Viruses first referring to the "severe acute respiratory syndrome coronavirus 2 (SARS-CoV-2)" and WHO to "COVID-19" as in coronavirus disease 2019 as of February 11, 2020 (World Health Organization, 2020b). 
By then, the sole virus-free regions seemed to be Africa and South America, though it might have been a matter of insufficient testing. In Europe, most cases were reported in France, Germany, the UK, and Italy. But as February progressed, the most worrying reports kept coming from Italy. In Spain, even if the Coordination Centre for Health Alerts and Emergencies was providing daily updates for mainstream media via its head, epidemiologist Fernando Simón, experts saw no reason for concern within national borders and, though there were cases reported coming from almost every region as well as deaths, mass demonstrations to celebrate International Women's Day on March 8 were allowed to take place. If at all, the public seemed to take an interest in what halting markets such as the Chinese might do to the global economy. Most people in Spain were reminded of the early 2000s financial crisis and its aftermath, but not many worried the latest coronavirus outbreak might mean a risk to their health. That the government and Ministry of Health failed to warn of lack of care in interactions while travel across borders was mostly still conducted without trouble meant controlling the spread of the virus was futile at best. Concerned citizens would see government officials and even the military on television almost daily with updates on rates and numbers of diagnoses and casualties. The official message was, in short, that Spain was doing relatively well in the midst of global chaos. On February 12, Fernando Simón insisted, "no hay coronavirus" ("there is no coronavirus") and therefore "no existe riesgo de infectarse" ("there is no risk of contagion"). To voices that were calling for stronger measures to be taken, he disdainfully rejected what he saw as social anxiety by minimizing the importance of face masks and sanitizers, calling such behavior as "un poco fuera de lo razonable" ("beyond what is reasonable") ("Minuto a minuto," 2020). He was sadly wrong, as time—and testing-would prove.

But how does the insidious concept of "crisis" permeate media discourse and seep into people's minds? Though etymologically "crisis" apparently stands for the ability to critically analyze a situation and look for solutions (Patrona, 2018, p. 2), due to its being "overused," it has become more and more difficult to define the specific features for an "event, series of events or phenomenon" to be categorized as such. Though of course fluctuating in meaning, crisis is a "mediated social practice" (p. 5), "socially constituted... talked into being in and through public discourses" (p. 5), constructed: "The performance of crisis lends itself to the discursive construction of specific, ideologically-imbued narratives" ( $p$. 6). These "narratives of crises" (p. 6) are all around us, a pervasive feature of our times. As Antoon De Rycker (2018) warns in his contribution to Crisis and the Media, one needs to approach with caution the "traumatic emotions 'doing crisis' engenders" (p. 41), not only because of those affects it generates, but also because of its role in homogenizing and downplaying difference. The label "crisis" turns "murky and troublesome challenges into a controllable phenomenon that can be identified, articulated, managed, and ultimately gotten rid of"' (Zelizer, 2015, p. 892).

\section{From a Narrative of "Crisis" to One of "War"}

The narrative of the crisis focused on tracking the virus, scientific jargon, statistics, and economic impact and led to an eventual declaration of a "state of emergency," in Spanish "estado de alerta," which provoked precisely that which it announced-acute alertnesscoupled with high levels of anxiety.

On Friday, March 13, 2020, Pedro Sánchez, President of the Government of Spain, gave a press conference to declare an unprecedented "estado de alarma" (Gobierno de 
España, 2020a). The following day, a Royal Decree specified what these exceptional measures entailed (Real Decreto 463/2020): movement was severely restricted, with citizens instructed to remain in their homes for a period of fifteen days just leaving for the utmost necessary activities such as going to work, to the supermarket, pharmacy, or to care for vulnerable persons. Educational activities would be subsequently conducted online. Retailers, museums, libraries, archives, sports facilities, bars, restaurants, and all activities deemed to pose a potential risk of infection were closed/banned. It was suggested that non-essential jobs be conducted from home but not regulated until 2 weeks later, when the number of deceased per day reached its then maximum of 832 (Menéndez, 2020), which meant the state of emergency was officially prolonged, and the lockdown hardened, with all non-essential workers forced to stay home. This halt, however, would just be in place from March 30 until April 9. Afterwards, though several peaks in contagion and death were reported, the return to work was allowed. The state of emergency, however, was renewed several times: on March 27, April 10, April 24, May 8, May 22, and June 5 (Real Decreto $555 / 2020$ ). Hence, a new period of "Plan de Desescalada" ("de-escalation plan") or "Transición hacia una Nueva Normalidad ("transition towards a new normalcy") would ensue, with gradually easing measures. Approved on April 28 in a meeting of the Spanish Council of Ministers (Gobierno de España, 2020b), the Plan organized measures in phases, from 0 to 3, depending on the health situation within each geographical area, which would eventually be followed by the "new normalcy" we are currently experiencing.

In Spain, over the course of 2020 and most pointedly at the height of the pandemic within national borders, a particular semantic field grounded the discursive framing of the SARS-CoV-2 virus and COVID-19-war. In most political actors' public interventions, the pervasiveness of the word "war" and related metaphors is all too evident.

In a special feature for Spanish newspaper El Mundo, Manuel Marraco, in conversation with Inés Olza (2020b), summarized the consequences of the war rhetoric mobilized by President of Spain Pedro Sánchez. Between March 13 and May 2, i.e., from the moment he publicly announced the nationwide state of emergency until he did the start of the de-escalation, Sánchez appeared on television 11 times, mentioning the word "guerra" (Spanish for "war") up to 40 times, in combination with related words such as "conflicto" (conflict), "combate" (combat), "batalla" (battle), "lucha" (fight), and "enemigo" (enemy). Of note are the 32 mentions of "fight" and 29 for "battle" and 33 for "enemy." But the heightened tone of his public addresses to the nation on public television featured more than a repetition of key terms. It consisted in creating a certain bellicose atmosphere as if we were in the midst of an actual war and patriots were being called to arms. Chronologically, it is easy to track this war narrative building up in Sánchez's speeches:

Me gustaría apelar directamente a los compatriotas. La victoria depende de cada uno de nosotros, en nuestro hogar, en nuestra familia, en el trabajo, en nuestro vecindario. El heroísmo consiste, también, en lavarse las manos, en quedarse en casa y en protegerse uno mismo, para proteger al conjunto de la ciudadanía (Secretaría de Estado de Comunicación, 2020a; emphasis added).

[I would like to appeal directly to my compatriots. Victory depends on each one of us, in our homes, at work, in our neighborhood. Heroism also consists in washing one's hands, staying home and protecting oneself so as to protect the whole of the Spanish citizenship.]

Arguably meant to flatten out regional differences and discourage separatist leanings, the President was making a call to citizens to be enrolled in a sort of communal effort and, like the inheritors of the communist party with whom he shares power, he calls on 
"comrades" often, here in the adjacent word "compatriots." Discipline is thus formulated in quite positive terms, by linking it to "victory" and "heroism," where handwashing and social distancing become examples of how regular citizens might become heroes in their everyday lives. But the "enemy" was lurking in the shadows, as Sánchez's following address, the very next day, showed:

estamos ante nuestro verdadero enemigo, que es el virus y la pandemia. Es un enemigo de todos y todos debemos combatirlo unidos. ... el objetivo en esta batalla contra el virus es primero reducir su propagación, después detenerla y, por fin, eliminarlo.

Tenemos por delante semanas difíciles, de esfuerzos y sacrificios. Esos esfuerzos y sacrificios empezarán a dar fruto ...

La victoria sobre el virus comenzará ...

La victoria será mayor ...

... la victoria será total ...

Permitidme concluir haciendo un reconocimiento público a quienes están colaborando en esta batalla contra la enfermedad: A los profesionales de la salud que sois ejemplo de heroicidad con vuestra entrega y vuestro trabajo, gracias. (Secretaría de Estado de Comunicación, 2020b, p. 11; emphasis added).

[we are facing our true enemy, the virus and the pandemic. It is a common enemy and we must fight it together. ... the aim in this battle against the virus is, first, to reduce its propagation, then stop it, and finally eliminating it.

We have difficult weeks ahead of us, of efforts and sacrifices. Those efforts and sacrifices will begin to bear fruit ...

Victory over the virus will begin ...

Victory will be greater...

... victory will be total ...].

Calling for an end of political and regional strife, Sánchez has sought to instill in people's minds the idea that no human being is an enemy, but a virus and the disease it causes. That is the invisible enemy one needs to fight. Repeating positive instead of negative words, he also emulated great leaders of former wars. Further, he came close to speaking as if he was a top military man before his troops: "Comparezco de nuevo para cumplir con mi deber de informar sobre la marcha del combate contra la pandemia del coronavirus" (Secretaría de Estado de Comunicación, 2020c; emphasis added) [I am here to fulfil my duty of informing on the ongoing combat against the coronavirus pandemic]. And it was precisely then, on March 21, that an open war was declared on the virus:

esta situación es la más grave que han vivido nuestras sociedades desde la II Guerra Mundial ... En nuestro país, ciertamente, solo los muy mayores, que conocieron las penalidades de la guerra civil y de la postguerra, guardan en su memoria situaciones colectivas más duras que las presentes. Salvo ellos, el resto de las generaciones que hoy vivimos en España nunca, jamás a lo largo de nuestras vidas, habíamos tenido que afrontar colectivamente algo tan duro, tan difícil. (Secretaría de Estado de Comunicación, 2020c; emphasis added).

[this situation is the hardest our societies have lived since WWII... In our country, only the elderly, who knew the hardship of the civil war and postwar periods, keep in their memory collective situations even harder than at present. But for them, other generations living in Spain had never in their lives had to face something so hard, so difficult, on a collective basis.] 
This particular extract combined in a couple of sentences some of the most traumatic events for our elders, and, though Sánchez's impassioned speech might seem otherwise directed at raising people's spirits, in line with what many have labeled as an attempt at becoming a Spanish Churchill (see Olza, 2020b), its impact was quite the opposite, with the elderly population, particularly those whose minds are not working completely right, to wonder about and fret before a potential war again. The news kept remarkable silence about this worrying rhetoric and what it caused in vulnerable minds. It will be years before one can assess to what extent it did the damage some of us have noted around us. Not just the elderly were affected by these affectively charged allocutions full of battlefront references. Scholars of trauma have noted that the ghosts of the past influence how other generations behave, even if unwittingly so. The Spanish Civil War and postwar dictatorship has left wounds akin to "transgenerational trauma" (Valverde and Martín-Cabrera, 2015):

Many people in Spain do not realize the role of fear in their everyday life. In a workshop on transgenerational trauma, a participant told an anecdote about a woman in his town. One night she heard people yelling outside her window. She opened up the window and saw hundreds of people shouting while carrying flags. She went into a state of panic that lasted for a few days while she kept repeating, almost in a trance: "Something is going to happen, something is going to happen." In reality those shouting were celebrating the victory of their soccer team. (Valverde and MartínCabrera, 2015, p. 217).

Irrelevant as it may seem, this display of terror is by no means an isolated occurrence. The post-conflict third generation carries with them a trauma that has been passed down to them and that means at times a certain level of anxiety and fear towards outer manifestations such as flags and appeals to patriotism, whatever the side one's grandparents were on. The first half of the twentieth century in Spain was so filled with violence and repression, it is of little wonder that "fear and the silence that fear provokes are still present in Spain today" (Valverde and Martín-Cabrera, 2015, p. 215).

With not many contesting voices against the deployment of war rhetoric, however, Sánchez continued to speak of war efforts and the need to be brave in the face of hardship:

... la sociedad española tiene generosidad y valentía, esa energía de sobra para afrontar y ganar la guerra al virus y a las consecuencias sanitarias, sociales y económicas que conlleva la guerra contra el virus. (Secretaría de Estado de Comunicación, 2020c; emphasis added).

[Spanish society is generous and brave, sufficient energy to face and win the war against the virus as well as the health, social and economic consequences of the war against the virus.]

In later public addresses, President Sánchez would continue this trend to energetically repeat the word "guerra." Suffice it to say here that, to a large extent, the media implemented this rhetoric instead of denouncing it, which would take grassroots activism and academia to work hand in hand to problematize it, bring it to public awareness, and hopefully dismantle it.

The overemphasis on "war" language was a worrying trend that needed to be addressed and redressed, as Inés Olza among others soon realized, launching the initiative online \#ReframeCovid, now a website ("\#ReframeCovid," 2020) as well as a hashtag on Twitter. As Olza explained, the mobilization of the hashtag and accompanying site is not a project, but a social initiative and a "collective movement" where academics in the humanities have an opportunity to act as "mediators" in addressing the radical need for alternative frames 
(Olza and Sobrino, 2020). It is a call for action, seeking to enroll and soliciting engaged, active citizen participation, mostly to be carried out online, at a time where lockdown made social media engagement an outlet to raise concerns.

Scholars of testimonial life writing have found that narrators usually rely on existing templates and frameworks of reference. Thus, for example, Schaffer and Smith (2004) remind readers that, like other human rights-related texts, testimonial life narratives are "placed within ethical and moral frameworks in order to solicit empathy and understanding" (p. 44). Of those, perhaps one of the most recurrent is the Holocaust, which has become "a template for all forms of traumatic telling, response, and responsibility" ( $p$. 20). Those representational frames are designed to capture "interest, empathy, and political responsiveness" (p. 27). But deploying "strategic frames" in one's narrative should not make readers/audiences wary. Quite the opposite: the "'strategic wielding of emotions' (Martínez García, 2018, p. 492) and strategic framing of the story ... serves to reach an ever-widening audience with the intention of provoking an empathic response" (Martínez García, 2019c, p. 73). Using repetition as a rhetorical device since Aristotle has been a distinctly successful mechanism for orators and public speakers to persuade citizens, politicians trying to win voters over included. Multimodal repetition across media and platforms, moreover, in the "digital society" (Lindgren, 2017) in which we are currently living, affords the promotion of awareness and engagement (Martínez García, 2020b, 2020c). In the case of COVID-19, however, the excessive repetition of terms that carry negative connotations such as "war," "fight," "battle," or even "crisis" does not lead to increased public engagement. Rather, it provokes rejection, fatigue, and disenchantment, to say the least. It follows, then, as Olza (2020a, 2020b) and others (Castelo Heymann and Szulman, 2020) have been suggesting, we need new "frames"-in other words, new ways of narrating this particular crisis. Repetition of certain phrases and words could, then, be positive, provided the war paradigm was replaced by another more helpful discourse, more in line with social movements and human rights campaigns, calling on solidarity and compassion, rather than appealing to vague violence against the unknown. The alternative might help reframe the way we as individuals and as a society address this crisis.

\section{Collective Acts of Memory}

To learn from the past and guide us in how to reshape the current panorama of media discourse on the COVID-19 crisis, one can turn to collective or cultural memory.

While the idea of "collective memory" was coined in the 1920s in France by Maurice Halbwachs (1997), it remains a contested term due to its apparent emphasis on the collective, and group dynamics, over the individual: "Nos souvenirs demeurent collectifs, et ils nous sont rappelés par les autres, alors même qu'il s'agit d'événements auxquels nous seul avons été mêlé, et d'objets que nous seuls avons vu" [Our memories become collective, and they are prompted on us by others while they relate events in which we were involved and things that were seen only by us] (p. 52). I quite agree with Michael Rothberg's (2009) reading of Halbwachs's "collective memory" as the understanding that "all memories are simultaneously individual and collective" (p. 15). But, though very much connected, to avoid the problematic term, others, like Astrid Erll and Ansgar Nünning (2010), propose "cultural memory" instead. "Cultural memory" is defined by Mieke Bal (1999) as "a cultural phenomenon as well as an individual or social one" (p. vii) "link[ing] the past to the present and future" (p. vii) in productive ways, countering the damaging effects of trauma, 
giving them voice and space, through "acts of memory" (p. xii). For Max Saunders (2010), apart from its discursive performativity, "the concept of cultural memory ... is concerned not with actual events but their cultural repercussions; not with actual memories but with memories as representations, and with representations of memories" (p. 330).

In testimonial narratives, it would be not only misleading but inappropriate to focus solely on the trauma experienced by individuals:

Those who testify speak on behalf of a collective and about collective trauma, such as genocide, dispossession, slavery, removal. These are catastrophic events that are visited upon a people, they are not the fate of tragic individuals. To individualize and psychologize testimonial traces of social suffering ... is to misrepresent a key feature of social suffering: this is collective historical trauma. (Whitlock, 2015, p. 68).

Calling Western trauma theory into question, Whitlock (2015) insists on the insidious nature of violence and suffering. The paradox, however, is that violence must be represented in order to be resisted, which leads to what Wendy S. Hesford (2011) terms a "crisis of witnessing" (p. 99), whereby there are certain "risks" (p. 99) attached to such representations, "ruptures in identification" (p. 99) and ultimately an "impossibility of empathetic merging ... that is aesthetically and politically staged" (p. 99). Much of the problematic belying testimony, she concludes, stems from its "mediated nature" (p. 99).

As individual and collective memories are entwined, they are indeed heavily "mediated" (Van Dijck, 2007) and imbued with strong feelings. Inevitably, talk of war in Spain necessarily takes one back to the Civil War which wounds are not quite healed, something contributions to the past 2 years' International Year in Review feature of the journal Biography (Martínez García 2019a, 2020a) show by looking at several biographies, memoirs, and documentaries that try to handle this complex legacy.

\section{Retraumatizing Our Elders}

The largest group affected by the SARS-CoV-2 virus - and the one whose survival rate and prognosis is worse-is precisely the elderly. Now, constantly reminiscing the war and postwar periods they either experienced or where close witnesses to, as shown above, potentially subjects our elders to unnecessary retraumatization.

Ever since the start of the enforced self-isolation or lockdown last March 2020, they have been overwhelmed by all this talk of war and postwar, and their aging rambling mind goes back to all those years and the hardship they endured and witnessed, to stories of hunger and deprivation, families ruined, alcoholism, and a whole range of too personal traumas to be disclosed. Silence is, as Armañanzas Ros $(2012,14)$ suggests, the main carrier of the hidden postwar trauma in Spain, with most second, third, and fourth generations learning the truth after many years, sometimes even after one relative dies.

Recollections of the pain of losing loved ones to famine, of siblings maimed or even killed by inexplicable, incurable diseases like polio, feeling insurmountable difficulties looming in the horizon, not quite grasping why there are so many deaths around them, and so much more, is in the minds of the elderly during the COVID-19 pandemic. Every time this vocabulary of war, fighting, surviving, etc., comes up, they are reminded of the war and postwar traumas. This revisiting the past, conducted in the chiaroscuro of enforced isolation, serves not to heal those wounds, but to reopen them. 
The complexity of those memories cannot fully or simply be comprehended by later generations. But, knowing our elders did live through traumatic times and to a greater or lesser extent experienced posttraumatic disorder (PTSD) symptoms in the postwar years, one can only accept that what emerges as complex images and feelings is part of a retraumatization process. PTSD, after all, is evidenced by intrusive memories-flashbacks assaulting the traumatized subject's present, avoidance-wishing to forget about the past, and hyperarousal-extreme vigilance and alertness (APA, 2000). New traumatic events, though of a different kind (torture, rape, murder cannot be compared with the compulsory lockdown and emergency measures during the pandemic), can be "new stressors" and therefore trigger PTSD symptoms (Schock and Knaevelsrud, 2013, p. 65). In the absence of appropriate care-both physical and psychological—for the elderly, with cutdowns on the mental healthcare system as a result of the 2008 economic crisis, and more possibly soon to come, how can they receive help, let alone treatment?

What consequences does the prolonged state of being confined, isolated, in lockdown, over an extended period of time-here, well over two months-have for one's psyche? Scholars have studied this issue in relation to prison inmates (Metzner and Fellner, 2010) and how they deal with immobility. More recently, the so-called refugee crisis in Europe brought to the fore the damaging consequences for asylum seekers minds' when placed in detention centers without an exit date (von Werthern et al., 2018; see also Whitlock, 2008).

These are of course highly different cases. After all, most of us are confined to the relative luxury of our homes, which should mean comfort and security. But there are exceptions. Many have noted the dire strain this imposes on women being forced to cohabit, practically imprisoned with, their abuser at home (see Bradbury-Jones and Isham, 2020; Kumar and Rajasekharan Nayar, 2020).

And what of the belated-and/or solely online-grieving and mourning for the departed loved ones? What about the elderly living alone who do not understand any of this?

Technology is offering support to the aforementioned groups, for which we should be grateful. Yet, what of the digital divide? Not everybody has access to the Internet nor knows how to use it.

How do we account for the dilemma between wanting to help, to "be" there, and being forbidden to do so by the authorities? How do we cope with so-called relaxation measures (Ruiz Sierra, 2020)—or "easing measures" (Gobierno de España, 2020c) that decide, theoretically in the citizens' best interests, it is safer to meet your friends to party, drink at a bar or go to the gym, before one can visit one's family, and all just because they happen to live three-to-four hours away?

Looking to the future makes societies move forward, but we should not forget our heritage and the role our elders played and can still play in our lives. It is quite painful to contemplate so many who have died alone in a room or out in the open without somebody holding their hand or kissing them goodbye. Can we go out of this crisis and emerge on the other side with a deeper care for families? Can we learn to value what we have?

\section{Rehumanizing an Inhuman Crisis}

An avenue for radical action now in our hands could be to start by changing the narrative. We need other metaphors apart from military ones, and we need them urgently: Metaphors and narratives that will not contribute - as current ones do- to the mental health crisis 
some of us are experiencing and new discursive frames, which can provide a new lens to grasp reality and the interconnections or bonds that hold us together, not divide us.

We need "personal stories that are able to both appeal to and to move people because of the emotional impact those stories have, beyond the cold data of statistics" (Martínez García, 2019b, p. 202). We should often be reminded-unlike the trend these days in mass media and politicians' public addresses - that we are not numbers, we are people, each of us with their particular story and feelings, context, and values. We need to try to understand ourselves and others to gain fuller awareness of the social world in which we live and "balance," as Brian Schiff (2020) rightly put it in his Q\&A the first day of The Psychology of Global Crises conference, "try[ing] to keep as best we can the social body healthy." In the face of trauma, past and present coalesce, memories reemerge but are reshaped in the process of mediation. Just as there are many crises apart from the medical emergency, there are many traumas that may become conflated as "certainty gives way to uncertainty" (Frie, 2020). The war and postwar trauma experienced by our elders is an example. If we wish to come out of this crisis as a society, we can neither disregard nor overemphasize its existence. But as second- and third-person recipients, Spaniards are placed, like other witnesses to trauma, "in a position of terrible responsibility ... to trauma story that continues to circle and carry affective force" (Whitlock, 2008, p. 213). As we go about the task of reconstructing the social fabric, perhaps we can reframe these times of crisis as a human experience, focusing on what we share. As carriers of a collective history, we should "co-construct" (see Gilmore, 2017) a reconfiguration of our past, present, and future.

Initiatives such as \#ReframeCovid (“\#ReframeCovid,” 2020) and \#UnaHistoriaMásHumana-a student-led initiative to record and archive the personal experiences of others so that future generations will look back on this period of time and find "a more humane history," consisting of more "human" stories than the mere facts relayed in the news or the success stories that abound (Boned, 2020)—may be examples of possible ways forward, asking people for their collaboration as we try to rethink what the future may be, what it might look like. As Molly Andrews (2020) eloquently argued in her thought-provoking plenary at The Psychology of Global Crises conference, after this "rupture of the everyday," we should find "new hoped for futures" that, as she then expanded in the Q\&A session, allow us to rethink how we want to live our lives "as individuals but also as communities." In the words of philosopher Mariano Crespo (2020), "we must understand that the common good is much more than the sum of individual goods, that our individual actions have social repercussions ... However, theoretical understanding is not enough. Our hearts and feelings must be shaped by reason."

We construct our future through personal choices (Aurell, 2020) and habits (González, 2020). In this "unexpected crossroads" (González, 2020), in the words of philosopher Ana Marta González, we should reflect on what we can do to "make the world a bit more humane" (González, 2020).

Are we learning from this "crisis" as many assert (Jones, 2020; Arango, 2020; Lee, 2020), to prepare ourselves for future crises? What should be done to lessen the harm made by war rhetoric and measures?

The solution may be to consider the implications of living through crisis, which is a rupture of the everyday for us, but not so much for others, an opportunity to see those who surround us as human beings in their own right, entitled to the same freedoms and rights as us, a potential to come closer and bridge the gap between the sadly frequent tendency towards neglecting and othering practices, particularly in public discourse. Let us find spaces of reconciliation that can bring people together across difference, acknowledging and learning to value those differences which, after all, make us human. Our identities are always in 
the making, relational, created, and recreated. "We're all fundamentally dependent on one another" (Frie, 2020). Understanding that "no man is an island" will prove crucial, if we are to value solidarity and relationality, seeing those around us as part of who we are.

Acknowledgments A version of this article was presented at The Psychology of Global Crises conference, which took place virtually May 20-30, 2020. Hosted by The American University of Paris, I am grateful to the organizers for the opportunity to share my research then and to publish its results herein. I am also grateful to the readers for their helpful feedback in revising this manuscript for publication.

Conflict of Interest The author declares that she has no conflict of interest.

\section{References}

American Psychiatric Association (APA). (2000). Diagnostic and statistical manual of mental disorders(4th $\&$ rev. ed.). Washington, DC: American Psychiatric Association.

Andrews, M. (2020, May 21). Global crisis and the failure of the narrative imagination [keynote presentation]. The Psychology of Global Crises online conference, American University of Paris. https://www. youtube.com/watch?v=Sxf7GJ7khvg

Arango, C. (2020). Lessons learned from the coronavirus health crisis in Madrid, Spain: how COVID19 has changed our lives in the last two weeks. Biological Psychiatry, 88(7), E33-E34. https://doi. org/10.1016/j.biopsych.2020.04.003

Armañanzas Ros, G. (2012). Elaboración transgeneracional del trauma: Guerra Civil española. Norte de salud mental, 10(43), 13-17.

Aurell, J. (2020). El significado histórico de la pandemia (p. 30). Nuestro tiempo: Spring.

Bal, M., Crewe, J., \& Spitzer, L. (Eds.). (1999). Acts of memory: cultural recall in the present. Hanover, NH: University Press of New England.

Boned, A. (2020). Una historia más humana. Retrieved from https://www.unahistoriamashumana.com/

Bradbury-Jones, C., \& Isham, L. (2020). The pandemic paradox: the consequences of COVID-19 on domestic violence. Journal of Clinical Nursing, 29, 2047-2049. https://doi.org/10.1111/jocn.15296

Castelo Heymann, S., \& Szulman, M. (2020). El framing en la crisis. In A. Gutiérrez-Rubí \& C. Pont Sorribes (Coords.), Comunicación política en tiempos de coronavirus (pp. 28-33). Barcelona: Cátedra Ideograma-UPF de Comunicación Política y Democracia.

Crespo, M. (2020, April 29). European Day of Solidarity between generations: tackling the pandemic without neglecting elderly people or children. Instituto Cultura y Sociedad. Retrieved from https://www. unav.edu/en/web/instituto-cultura-y-sociedad/actualidad/detalle-noticias/2020/04/29/european-day-ofsolidarity-between-generations\%3A-tackling-the-pandemic-without-neglecting-elderly-people-or-child ren/-/asset_publisher/XNc0/content/2020_04_29_ics_dia_solidaridad/10174

De Rycker, A. (2018). Reconceptualizing crisis: 'doing crisis' as a (recontextualized) social practice. In M. Patrona (Ed.), Crisis and the media: narratives of crisis across cultural settings and media genres (pp. 33-56). Amsterdam: John Benjamins.

Eakin, P. J. (1999). How our lives become stories: making selves. Ithaca: Cornell University Press.

Eakin, P. J. (2008). Living autobiographically: how we create identity in narrative. Ithaca: Cornell UP.

Erll, A., \& Nünning, A. (Eds.). (2010). A Companion to cultural memory studies. Berlin: Walter de Gruyter.

Frie, R. (2020, May 22). Living with vulnerability: fear and resilience in the age of coronavirus and social trauma [keynote presentation]. The Psychology of Global Crises online conference, American University of Paris. https://www.youtube.com/watch?v=0TvtpUtHsMI

Gilmore, L. (2017). Testimony. a/b: Auto/Biography Studies, 32(2), 307-309. https://doi.org/10.1080/08989 575.2017 .1288957

Gobierno de España. (2020a, March 13). Institutional statement by President of the Government to announce state of emergency due to coronavirus crisis. Retrieved from https://www.lamoncloa.gob.es/ lang/en/presidente/intervenciones/Paginas/2020/20200313state-emergency.aspx

Gobierno de España. (2020b, April 28). El Gobierno aprueba un plan de desescalada que se prolongará hasta finales de junio. Retrieved from https:/www.lamoncloa.gob.es/consejodeministros/resumenes/ Paginas/2020/280420-consejo_ministros.aspx

Gobierno de España. (2020c, May 3). Plan para la transición hacia una nueva normalidad: respuestas a preguntas frecuentes. Retrieved from https://www.lamoncloa.gob.es/serviciosdeprensa/notasprensa/ sanidad14/Documents/2020/03052020_Desescalada.pdf 
González, A. M. (2020, March 16). COVID-19: a call to reflect on our social and development models. Instituto Cultura y Sociedad. Retrieved from https://www.unav.edu/en/web/instituto-cultura-y-socie dad/actualidad/detalle-noticias/2020/03/16/covid19\%3Aa-call-to-reflect-on-our-social-and-devel opment-models/-/asset_publisher/XNc0/content/2020_03_16_ics_entrevista_anamarta_gonza lez/10174

Halbwachs, M. (1997). La mémoire collective. 1950. Ed. Gerard Namer. Paris: Albin Michel.

Hesford, W. S. (2011). Spectacular rhetorics: human rights visions, recognitions, feminisms. Durham, NC: Duke University Press.

Jones, D. S. (2020). History in a crisis-lessons for Covid-19. New England Journal of Medicine, 382, 1681-1683. https://doi.org/10.1056/NEJMp2004361

Kumar, A., \& Rajasekharan Nayar, K. (2020): COVID 19 and its mental health consequences, Journal of Mental Health, 1-2. https://doi.org/10.1080/09638237.2020.1757052

Lee, T. H. (2020). Creating the new normal: the clinician response to COVID-19. NEJM Catalyst Innovations in Care Delivery, 1(2). doi: https://doi.org/10.1056/CAT.20.0076

Lindgren, S. (2017). Digital media \& society. London: SAGE.

Martínez García, A. B. (2018). TED Talks as life writing: online and offline activism. Life Writing, 15(4), 487-503. https://doi.org/10.1080/14484528.2017.1405317

Martínez García, A. B. (2019a). Auto/biography and conflict: the year in Spain. Guest essay. Biography, 42(1), 147-153. https://doi.org/10.1353/bio.2019.0022

Martínez García, A. B. (2019b). Construction and collaboration in life-writing projects: Malala Yousafzai's activist 'I.' Journal of Writing in Creative Practice, 12(1 \& 2), 201-217.

Martínez García, A. B. (2019c). Denouncing human trafficking in China: North Korean women's memoirs as evidence. State Crime Journal, 8(1), 59-79. https://doi.org/10.13169/statecrime.8.1.0059

Martínez García, A. B. (2020a). Giving voice to silenced others: the year in Spain. Biography, in press.

Martínez García, A. B. (2020b). New forms of self-narration: young women, life writing and human rights. Cham: Palgrave.

Martínez García, A. B. (2020c). Women activists' strategies of online self-presentation. AI \& Society: Journal of Knowledge, Culture and Communication: Special Issue on Iteration as Persuasion in a Digital World, in press.

Menéndez, M. (2020, March 28). El Gobierno endurece el confinamiento y paraliza todas las actividades salvo las esenciales desde el lunes.Rtve. Retrieved from https://www.rtve.es/noticias/20200328/ sanchez-anuncia-paralizacion-todas-actividades-salvo-esenciales-desde-este-lunes/2011000.shtml

Metzner, J. L., \& Fellner, J. (2010). Solitary confinement and mental illness in U.S. prisons: a challenge for medical ethics. Journal of the American Academy of Psychiatry and the Law, 38(1), 104-108.

Minuto a minuto. (2020, February 14). 20 Minutos. Retrieved from https://www.20minutos.es/notic $\mathrm{ia} / 4146540 / 0 /$ directo-coronavirus/

Olza, I. (2020a, 20 April). \#ReframeCovid, la apuesta contra el lenguaje bélico (interview by Gema Santamaría). $A B C$, p. 44.

Olza, I. (2020b, 10 May). Las 40 guerras de Sánchez (interview by M. Marraco). El Mundo, pp. 24-27.

Olza, I., \& Sobrino, P. P. (2020, May 19). \#ReframeCovid: In conversation with Inés Olza and Paula Pérez Sobrino. Retrieved from https://www.youtube.com/watch?v=69DMohznrtM

Patrona, M. (Ed.). (2018). Crisis and the media: narratives of crisis across cultural settings and media genres. Amsterdam: John Benjamins.

Real Decreto 463/2020, de 14 de marzo, por el que se declara el estado de alarma para la gestión de la situación de crisis sanitaria ocasionada por el COVID-19. (2020). Boletín Oficial del Estado, no. 67, Section I, pp. 25390-25400. Ref. BOE-A-2020-3692. Retrieved from https://www.boe.es/eli/ es/rd/2020/03/14/463/con

Real Decreto 555/2020, de 5 de junio, por el que se prorroga el estado de alarma declarado por el Real Decreto 463/2020, de 14 de marzo, por el que se declara el estado de alarma para la gestión de la situación de crisis sanitaria ocasionada por el COVID-19. (2020). Boletín Oficial del Estado, no. 159, Section I, pp. 38027-38036. Ref. BOE-A-2020-5767. Retrieved from https://www.boe.es/boe/ dias/2020/06/06/pdfs/BOE-A-2020-5767.pdf

\#ReframeCovid. (2020). Retrieved from https://sites.google.com/view/reframecovid/home

Rothberg, M. (2009). Multidirectional memory: remembering the Holocaust in the age of decolonization. Stanford: Stanford University Press.

Ruiz Sierra, J. (2020, April 7). El Gobierno evita aclarar las medidas de relajación: "No queremos especular." El Periódico. Retrieved from https://www.elperiodico.com/es/politica/20200407/gobierno-conse jo-de-ministros-maria-jesus-montero-evita-aclarar-medidas-relajacion-confinamiento-7920467

Saunders, M. (2010). Life-writing, cultural memory, and literary studies. In A. Erll \& A. Nünning (Eds.), A companion to cultural memory studies (pp. 322-331). Berlin: Walter de Gruyter. 
Schaffer, K., \& Smith, S. (2004). Human rights and narrated lives: the ethics of recognition. New York: Palgrave Macmillan.

Schiff, B. (2020, May 20). The hermeneutics of crisis and the crisis of interpretation [keynote presentation]. The Psychology of Global Crises online conference, American University of Paris. https://www.youtu be.com/watch?v=jZ3RD0Q1BuI

Schock, K., \& Knaevelsrud, C. (2013). Retraumatization: the vicious circle of intrusive memory. In M. Linden \& K. Rutkowski (Eds.), Hurting memories and beneficial forgetting: posttraumatic stress disorders, biographical developments and social conflicts (pp. 59-70). London: Elsevier.

Secretaría de Estado de Comunicación. (2020a, March 13). Declaración institucional del presidente del gobierno sobre el estado de alarma en la crisis del coronavirus. Retrieved from https://www.lamoncloa. gob.es/presidente/intervenciones/Documents/2020/20200313\%20PG\%20Estado\%20de\%20Alarma.pdf

Secretaría de Estado de Comunicación. (2020b, March 14). Comparecencia del presidente del Gobierno tras la declaración del estado de alarma por el Consejo de Ministros. Retrieved from https://www.lamon cloa.gob.es/presidente/intervenciones/Paginas/2020/prsp14032020.aspx

Secretaría de Estado de Comunicación. (2020c, March 21). Comparecencia del presidente del gobierno sobre el coronavirus. Retrieved from https://www.lamoncloa.gob.es/presidente/intervenciones/Pagin as/2020/prsp21032020.aspx

Valverde, C., \& Martín-Cabrera, L. (2015). The silence of the grandchildren of the Civil War: transgenerational trauma in Spain. In M. O'Loughlin (Ed.), The ethics of remembering and the consequences of forgetting: essays on trauma, history, and memory (pp. 203-228). Lanham, MD: Rowman \& Littlefield.

van Dijck, J. (2007). Mediated memories in the digital age. Stanford: Stanford University Press.

von Werthern, M., Robjant, K., Chui, Z., Schon, R., Ottisova, L., Mason, C., \& Katona, C. (2018). The impact of immigration detention on mental health: a systematic review. BMC Psychiatry, 18(1), 1-19. https://doi.org/10.1186/s12888-018-1945-y

Whitlock, G. (2008). Letters from Nauru. Life Writing, 5(2), 203-217. https://doi.org/10.1080/1448452080 2393218

Whitlock, G. (2015). Postcolonial life narratives: testimonial transactions. Oxford: Oxford University Press.

World Health Organization. (2020a, January 30). WHO Director-General's statement on IHR Emergency Committee on Novel Coronavirus (2019-nCoV). Retrieved from https://www.who.int/dg/ speeches/detail/who-director-general-s-statement-on-ihr-emergency-committee-on-novel-coronaviru s-(2019-ncov)

World Health Organization. (2020b, February 11).Naming the coronavirus disease (COVID-19) and the virus that causes it. Retrieved from https:/www.who.int/emergencies/diseases/novel-coronaviru s-2019/technical-guidance/naming-the-coronavirus-disease-(covid-2019)-and-the-virus-that-causes-it

World Health Organization. (2020c, March 11). WHO Director-General's opening remarks at the media briefing on COVID-19 - 11 March 2020. Retrieved from https://www.who.int/dg/speeches/detail/whodirector-general-s-opening-remarks-at-the-media-briefing-on-covid-19-11-march-2020

Zelizer, B. (2015). Terms of choice: uncertainty, journalism, and crisis. Journal of Communication, 65(5), 888-908. https://doi.org/10.1111/jcom.12157 